\section{NOTICE}

THIS REFORT IS IIA

FHAT PRECLUDES SATI:A
ANL $/ E V / A P--84-1$

DE84 009419

\title{
SOME ASPECTS OF THE USE OF PROTON RECOIL PROPORTIONAL COUNTERS FOR FAST NEUTRON PERSONNEL DOSIMETERS
}

by

T. J. Yule ard E. F. Bennett

Applied Physics Division

Argonne National Laboratory

9700 South Cass Avenue

Argonne, Illinois 60439

January 1984

\section{DISCLAIMER}

This report was prepared as an account of work sponsored by an agency of the United States Government. Neither the United States Government nor any agency thereof, nor any of their employees, makes any warranty, express or implied, or assumes any legal liability or responsibility for the accuracy, completeness, or usefulness of any information, apparatus, product, or process disclosed, or represents that its use would not infringe privately owned rights. Reference herein to any specific commercial product, process, or service by trade name, trademark, manufacturer, or otherwise does not necessarily constitute or imply its endorsement, recommendation, or favoring by the United States Government or any agency thereof. The views and opinions of authors expressed herein do not necessarily state or reflect those of the United States Government or any agency thereof. 


\section{LEGIBILITY NOTICE}

A major purpose of the Technical Information Center is to provide the broadest possible dissemination of information contained in DOE's Research and Development Reports to business, industry, the academic community, and federal, state, and local governments. Non-DOE originated information is also disseminated by the Technical Information Center to support ongoing DOE programs.

Although large portions of this report are noi reproducible, it is being made available only in paper copy form to facilitate the availability of those parts of the document which are legible. Copies may be obtained from the National Technical Information Service. Authorized recipients may obtain a copy directly from the Department of Energy's Technical Information Center. 